\title{
PERAN IBU DALAM PROSES PENDIDIKAN ANAK USIA DINI MENURUT AL-QURAN
}

\author{
As'aduttabi'in, M. Pd.I. \\ Dosen Program Studi Pendidikan Agama Islam (PAI) \\ STAI Madinatunnajah Rengat, Indragiri Hulu \\ E-mail: A2d.al.andalasi@yahoo.com
}

\begin{abstract}
ABSTRAK
Peran seorang ibu dalam dunia pendidikan sangatlah penting baik dalam lingkungan keluarga maupun lingkungan sekitarnya, terutama bagi anak-anaknya yang masih tergolong dalam anak usia dini. Karena di usia dini inilah yang paling kritis dalam bentuk karakter dan kepribadian anak. Penelitian ini bertujuan untuk mengetahui bagaimana peran ibu dalam proses pendidikan anak usia dini menurut Al-Qur'an, hasil penelitian ini diharapkan dapat menambah wawasan dan pengetahuan penulis dan juga para ibu tentang fungsi dan peranannya dalam mendidik anak serta memberikan dorongan bagi pendidik dalam menghadapi kemajuan dan perkembangan zaman.

Penelitian ini merupakan penelitian pustaka (library research), dengan pendekatan psikologi dan menggunakan metode deskriptif sedangkan teknik pengumpulan datanya menggunakan metode dokumentasi.

Hasil penelitian menunjukkan bahwa seorang ibu memiliki peranan yang sangat penting dan tidak bisa dianggap ringan.

Beberapa teori mengungkapkan adanya masa pendidikan Prenatal sehingga memperkuat istilah pendidikan Minal mahdi ilal lahdi. Sehingga pribadi seorang ibu sebagai madrasah pertama bagi anak sangat menentukan kualitas pendidikan anak yang dikandungnya. Ibu adalah madrasah pertama dan utama bagi anak-anaknya, dimana anak mendapatkan asuhan, curahan kasih sayang dan kelembutan dari seorang ibu dan hal itu sangat pokok dan utama diperlukan bagi anak usia dini dalam kelanjutan dan perkembangannya, untuk itu materi dan metode yang diberikan oleh seorang ibu dalam mendidik anaknya pada masa usia dini adalah dengan penanaman keimanan dan akhlak.
\end{abstract}

Kata Kunci: Peran Ibu Dalam Pendidikan Anak, Pendidikan Anak Usia Dini, Pendidikan Anak Usia Dini Menurut Al-Quran

\section{A. PENDAhuluan}

Pada dasarnya pendidikan pertama dan utama pada anak terdapat dalam keluarga, dalam keluarga terdapat beberapa komponen yaitu, ayah, ibu, kakak dan adik. Di sini selain sosok seorang ayah sebagai pendidik, juga terdapat yang lain di antaranya yaitu ibu. Sosok ibu inilah yang merupakan pendidik utama bagi anak- 
anaknya menuju kesuksesan, karena pendidikan yang diberikan seorang ibu terhadap anaknya merupakan pendidikan dasar yang tidak dianggap ringan. ${ }^{1}$

Dengan pendidikan, pribadi seseorang akan terbentuk, baik itu masalah akhlak maupun masalah keimanannya. Pendidikan tidak hanya terjadi di lembaga sekolah akan tetapi pendidikan juga terjadi di dalam lingkungan keluarga bahkan di dalam lingkungan masyarakat. Dan lingkungan keluargalah yang merupakan lembaga yang pertama kali berfungsi sebagai pendidik. Di sinilah terjadi pola interaksi yang intensif dalam proses pendidikan anak pada suatu keluarga, yang mana ibu sangat berperan penting dan sangat dominan dalam mendidik anakanaknya.

Allah SWT telah mendeskripsikan bahwa manusia harus berhati-hati menjaga amanah, karena anak juga bisa menjadi ujian keimanan bagi orang tuanya. Dalam firman-Nya,surat Al-Anfaal ayat 28 :

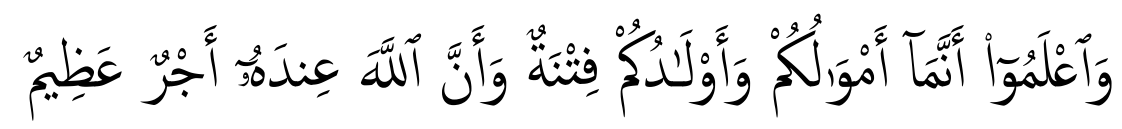

"Dan ketahuilah, bahwa hartamu dan anak-anakmu itu hanyalah sebagai cobaan dan sesungguhnya disisi Allahlah pahala yang besar"2

Terdapat dua aspek penting yang harus ditanamkan kepada anak-anak, khususnya kepada anak usia dini baik laki-laki maupun perempuan yakni aspek iman dan akhlak, sebagaimana yang dikisahkan dalam surat Luqman ayat 13 bahwa yang pertama kali diajarkan adalah tauhid (mengenal Tuhan).

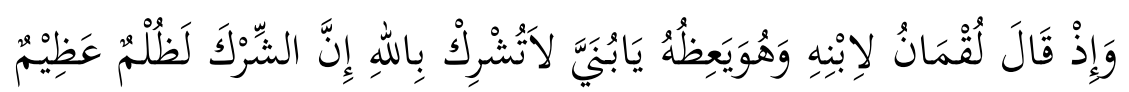

"Dan (ingatlah) ketika luqman berkata kepada anaknya, diwaktu ia memberi pelajaran kepadanya: "Hai anakku, janganlah kamu mempersekutukan Allah, sesungguhnya mempersekutukan (Allah) adalah benar-benar kezaliman yang besar",3

Kemudian dilanjutkan dengan pendidikan akhlak, yang juga dijelaskan dalam surat Luqman ayat 14-17 yakni menemukan relevansinya dengan potensi

1 Djumransyah, Pendidikan Islam Menggali "Tradisi", Meneguhkan Eksistensi. UIN-Malang Pres. Malang. 2007. Hlm 85

${ }^{2}$ Departemen Agama RI, Al-Qur'an dan Terjemahnya. CV. Penerbit J-ART. Bandung. 2005. Hlm 181

${ }^{3}$ Departemen Agama RI, Al-Qur'an dan Terjemahnya...HIm 413 
yang dimiliki anak. Dengan pembiasaan yang baik seperti penanaman aspek keimanan dan akhlak sejak anak usia dini, akan sangat mempengaruhi dan bahkan membentuk pribadi muslim, sebagaimana yang dicita-citakan oleh Islam.

Taqwa merupakan asas dari berbagai kebajikan, dan bahkan sebagai induk segala perbuatan dan ibadah manusia. Sedangkan iman merupakan pernyataan pembenaran dengan qolbu sehingga manusia terbebas dari perbuatan dusta. Menurut syari'at Islam, iman adalah I'tikad dalam qolbu dan ikrar dengan lisan yang diwujudkan dalam berbagai amalan dengan segala ketentuannya. Ini berarti, bahwa seorang yang beriman, pasti berserah diri kepada Allah SWT, artinya menjadi muslim hakiki. ${ }^{4}$

Dalam hal ini penulis ingin menyampaikan bahwa seorang ibu mempunyai fungsi dan peran yang sangat urgen dalam keluarganya, khususnya dalam membentuk pribadi-pribadi anaknya. Untuk membentuk pribadi seorang anak secara baik, seorang ibu hendaknya memahami dan mengerti dunia anak-anak mulai dari tahun pertama sampai pada usia anak sudah mampu berinteraksi dengan lingkungan sekitarnya (0-6 tahun).

\section{B. PEMBAHASAN}

\section{Pengertian Pendidikan Anak Usia Dini}

Sebelum menjelaskan pendidikan anak usia dini, terlebih dahulu akan dibahas makna dari pendidikan itu sendiri dan juga anak usia dini.

a. Pendidikan ialah segala usaha orang dewasa dalam pergaulan dengan anakanak untuk memimpin perkembangan jasmani dan rohaninya ke arah kedewasaan. ${ }^{5}$

b. Pendidikan diartikan sebagai latihan mental, moral, dan fisik yang bisa menghasilkan manusia berbudaya tinggi. Maka pendidikan berarti

\footnotetext{
4 Ahmad Tafsir, Pendidikan Agama Dalam Keluarga. PT. Remaja Rosdakarya. Bandung. 2002. Hlm 67

5 Ngalim Purwanto, Ilmu Pendiidkan Teoritis dan Praktis. Rosdakarya. Bandung. 2007. hlm 11
} 
menumbuhkan personalitas (kepribadian) serta menanamkan rasa tanggung jawab. ${ }^{6}$

c. Menurut John Dewey, pendidikan diartikan sebagai "social continuity of life". Adapun menurut Langeveld, pendidikan merupakan upaya manusia dewasa membimbing kepada yang belum dewasa untuk mencapai kedewasaan. ${ }^{7}$

Dalam pandangan Al-Qur'an sebuah transformasi baik ilmu maupun nilai secara substansial tidak dibedakan. Berangkat dari paradigma tersebut, maka di dalam Al-Qur'an terdapat beberapa istilah yang mengacu pada terminology "Pendidikan dan Pengajaran" diantaranya adalah tarbiyah.

Istilah tarbiyah dapat diartikan sebagai proses penyampaian atau pendampingan (asistensi) terhadap anak yang diampu sehingga dapat mengantarkan masa kanak-kanak tersebut ke arah yang lebih baik, baik anak sendiri maupun anak orang lain. ${ }^{8}$

Dalam pasal 1 butir 1 UU RI No. 20 Tahun 2003, disebutkan bahwa pendidikan adalah usaha sadar dan terencana untuk mewujudkan suasana belajar dan proses pembelajaran agar peserta didik secara aktif mengembangkan potensi dirinya untuk memiliki kekuatan spiritual keagamaan, pengendalian diri, kepribadian, kecerdasan, akhlak mulia serta keterampilan yang diperlukan dirinya, masyarakat bangsa dan negara. ${ }^{9}$

Dengan demikian para ahli pendidikan menetapkan bahwa pendidikan adalah proses perubahan tingkah laku yang dikehendaki dan pada kehidupan masyarakat. ${ }^{10}$ Adapun yang dimaksud dengan usia dini berdasarkan UU No 20. tahun 2003 tentang Sistem Pendidikan Nasional adalah kelompok manusia yang berusia 0-6 tahun. Anak usia dini adalah sekelompok anak yang berada dalam proses pertumbuhan dan perkembangan yang bersifat unik, dalam arti memilih

\footnotetext{
${ }^{6}$ M. Arifin. Ilmu Pendidikan Islam. Bumi Aksara. Jakarta.1996. hlm 10

${ }^{7}$ Mansur, Pendidikan Anak Usia Dini Dalam Islam. Pustaka Belajar. Yogyakarta. 2007, hlm 84

${ }^{8}$ Ahmad Munir, Tafsir Tarbawi: Mengungkap Peran Al-Qur'an Tentang Pendidikan. Teras. Yogyakarta 2008. Hlm 38

${ }^{9}$ Undang-Undang Republik Indonesia, Sistem Pendidikan Nasional 2008, hlm 2

${ }^{10}$ Erwin Yudi Prahara Cendikia, Jurnal kependidikan dan kemasyarakatan. STAIN Ponorogo. No. 1 Tahun 2005. Hlm 86
} 
pola pertumbuhan dan perkembangan (koordinasi motorik halus dan kasar), intelegensi (daya fakir, daya cipta, kecerdasan emosi dan kecerdasan spiritual), sosial emosional (sikap dan perilaku serta agama), bahasa dan komonikasi yang khusus sesuai dengan tingkat pertumbuhan dan perkembangan anak. ${ }^{11}$

Pendidikan anak usia dini adalah suatu upaya pembinaan yang ditujukan kepada anak sejak lahir sampai dengan usia enam tahun yang dilakukan melalui pemberian rangsangan pendidikan untuk membantu pertumbuhan dan perkembangan jasmani dan rohani agar anak memiliki kesiapan dan memasuki pendidikan lebih lanjut. $^{12}$

Dengan demikian pendidikan anak usia dini (PAUD) dapat dideskripsikan sebagai berikut:

a. Pemberian upaya untuk menstimulasi, membimbing, mengasuh, dan pemberian kegiatan pembelajaran yang akan menghasilkan kemampuan dan keterampilan pada anak.

b. Salah satu bentuk penyelenggaraan yang menitik beratkan kepada peletakan dasar ke arah pertumbuhan dan perkembangan fisik (koordinasi motorik halus dan kasar), kecerdasan (daya pikir, daya cipta, kecerdasan emosi dan kecerdasan spiritual), sosio-emosional (sikap perilaku dan agama), bahasa dan komunikasi.

c. Berdasarkan pada keunikan dan pertumbuhan pendidikan anak usia dini (PAUD) disesuaikan dengan tahap-tahap perkembangan yang dilalui oleh anak usia dini. ${ }^{13}$

Hasenstab dan Horner mengemukakan bahwa Pendidikan anak usia dini dimulai dari usia 3 tahun sampai dengan 6 tahun yang sering dikatakan sebagai pendidikan prasekolah, dan pada usia ini anak mengalami perkembangan yang sangat pesat baik fisik maupun psikis atau kejiwaan. ${ }^{14}$

\footnotetext{
${ }^{11}$ Mansur, Pendidikan Anak Usia Dini Dalam Islam...hlm 88

${ }^{12}$ UU RI, SISDIKNAS,2008, hlm 4

${ }^{13}$ Mansur, Pendidikan Anak Usia Dini Dalam Islam...hlm 88-89

${ }^{14}$ Mansur, Pendidikan Anak Usia Dini Dalam Islam...hlm 91
} 
Para pendidik anak usia dini (Young Children) mengemukakan istilah Eary Childhood (anak usia awal) dan Eary Childhood Education (pendidikan anak masa awal) adalah sama atau sinonim. Adapun istilah lain yang sering digunakan tentang pendidikan anak usia dini adalah Nursey school atau preschool (prasekolah). Nursey school adalah program untuk pendidikan anak usia dua, tiga dan empat tahun. Menurut The National Association For The Education istilah preschool adalah anak antara usia toddler (1-3 tahun) dan usia masuk kelas satu, biasanya antara 3 sampai 5 tahun. ${ }^{15}$

\section{Tujuan Pendidikan Anak Usia Dini}

Pentingnya terselenggaranya pendidikan anak usia dini (PAUD) tidak dapat dipisahkan dengan UU No. 20 tahun 2003 tentang Sistem Pendidikan Nasional (SISDIKNAS). Khususnya diatur dalam pasal 28, yang menyebutkan bahwa:

a. Pendidikan anak usia dini diselenggarakan sebelum jenjang pendidikan dasar.

b. Pendidikan anak usia dini dapat diselenggarakan melalui jalur pendidikan formal, nonformal dan atau informal.

c. Pendidikan anak usia dini pada jalur pendidikan formal berbentuk Taman Kanak-kanak (TK), Raudatul Athfal (RA) atau bentuk lain yang sederajat.

d. Pendidikan anak usia dini pada jalur pendidikan nonformal berbentuk kelompok bermain (KB), Taman Penitipan Anak (TPA), atau bentuk yang lain yang sederajat.

Pendidikan anak usia dini pada jalur pendidikan informal berbentuk pendidikan keluarga atau pendidikan yang diselenggarakan oleh lingkungan. Anak-anak usia di bawah 5 tahun (balita) adalah usia yang paling kritis atau paling menentukan dalam pembentukan karakter dan kepribadian seseorang. Termasuk juga pengembangan intelegensi, yang mana anak usia dibawah 5 tahun memiliki intelegensi laten (potential intelegence) yang luar biasa. ${ }^{16}$

\footnotetext{
${ }^{15}$ Mansur, Pendidikan Anak Usia Dini Dalam Islam...hlm 110

${ }^{16}$ Yuliati Hotifah. Egalita, Jurnal Kesetaraan \&Keadilan Gender...HIm 233
} 
Tujuan dari pendidikan anak adalah usaha mencari keridloaan Allah SWT dan usaha untuk mendapatkan surganya, keselamatan dari neraka serta megharapkan pahala dan balasannya. ${ }^{17}$

Namun tujuan pendidikan yang ingin dicapai oleh orang tua merupakan kewajaran. Tujuan tersebut erat kaitannya dengan ekspektasi orang tua tentang kehidupan relegius anak-anaknya. Sejak anak berada dalam ayunan ibunya, tujuan keimanan ditentukan oleh ibunya. Maka tujuan awal yang seyogyanya ditetapkan oleh orang tuanya ialah agar anak mampu menghayati suasana kehidupan relegius dalam kehidupan keluarga dan tujuan ini lebih berorientasi kepada tujuan yang ingin dicapai oleh orang tuanya. ${ }^{18}$

Hasenstab dan Horner mengemukakan bahwa salah satu tujuan dari pendidikan anak usia dini adalah memberikan pengalaman dan kesempatan yang akan membantu penguasaan kemampuan pada semua bidang perkembangan untuk meningkatkan kesempatan berhasil ketika anak memasuki jenjang pendidikan formal. $^{19}$

Sedangkan tujuan diselenggarakannya pendidikan anak usia dini yaitu:

a. Untuk membentuk anak Indonesia yang berkualitas yaitu anak yang tumbuh dan berkembang sesuai dengan tingkat perkembangannya sehingga mempunyai kesiapan yang optimal di dalam memasuki pendidikan dasar serta mengarungi kehidupan dimasa dewasa.

b. Untuk membantu menyiapkan anak mencapai kesiapan belajar (akademik) di sekolah. $^{20}$

\section{Fase Pertumbuhan dan Perkembangan Anak}

Bijou dalam bukunya Development in the Preschool Years a Fungsional Analisis, memetakan menjadi lima periode perkembangan yaitu: periode pra lahir (pembuahan sampai lahir), masa neonatus (lahir dari 10-14 hari), masa bayi

${ }^{17}$ Abu Amir Ahmad Sulaiman, Metode Pendidikan Anak Muslim Usia Prasekolah. Yayasan Al-Qur'anSofwa. Jakarta, 2000, hlm 8

${ }^{18}$ Ahmad Tafsir, Pendidikan Agama Dalam Keluarga...hlm 89

${ }^{19}$ Mansur, Pendidikan Anak Usia Dini Dalam Islam. Pustaka Belajar...hlm 93

${ }^{20}$ Yuliati Hotifah. Egalita, Jurnal Kesetaraan \&Keadilan Gender...HIm 232 
(2 minggu-2 tahun), masa anak-anak (2 tahun-remaja) yang terdiri dari 2 tahap, masa kanak-kanak dini (2-6 tahun) dan masa kanak-kanak akhir (6-13 tahun) serta masa puber (11-16 tahun). ${ }^{21}$

Pertumbuhan dapat diartikan sebagai perubahan kuantitatif pada material (unsur organ tubuh) sebagai akibat dari pengaruh lingkungan. Sedangkan perkembangan atau development berarti serangkaian perubahan progresif yang terjadi sebagai akibat dari proses kematangan dan pengalaman. Dapat diartikan juga bahwa perkembangan adalah perubahan kualitatif dari segi fungsi kepribadian akibat dari pertumbuhan dan pengalaman atau belajar. ${ }^{22}$ Pertumbuhan dan perkembangan merupakan proses alami yang terjadi dalam kehidupan manusia. Pertumbuhan lebih menitikberatkan pada pertumbuhan fisik yang bersifat kuantitatif. Sedangkan perkembangan yang bersifat kualitatif, berarti serangkaian perubahan progresif sebagai akibat dan proses kematangan dan pengalaman. ${ }^{23}$ Untuk mengembangkan berbagai potensi pada anak sejak dini, maka dikembangkan aspek-aspek pengembangan yakni: pengembangan moral dan nilai-nilai agama, pengembangan fisik, pengembangan bahasa, pengembangan kognitif, pengembangan sosio-emesional, pengembangan seni dan kreativitas. ${ }^{24}$

a. Perkembangan Fisik dan Motorik

Perkembangan fisik merupakan dasar bagi kemajuan perkembangan berikutnya. Proporsi tubuhnya berubah secara dramatis. ${ }^{25}$ Sedangkan perkembangan motorik ialah segala sesuatu yang ada hubungannya dengan gerakan-gerakan tubuh. Dalam perkembangan motoris, unsur-unsur yang menentukan ialah otot, saraf dan otak. Dalam hal tersebut motorik memegang peranan yang sangat penting, dengan bantuan motorik yang makin lama

\footnotetext{
${ }^{21}$ Dedi Sugiono, 19 Januari 2017, Peran Keluarga Dalam Pendidikan Usia Dini, Http://dedisugiono.wordpress.com

${ }^{22}$ Muhammad Azmi, Pembinaan Akhlak Anak Usia Prasekolah. Belukar. Yogyakarta 2006, hlm 96

${ }^{23}$ Mansur, Pendidikan Anak Usia Dini Dalam Islam. Pustaka Belajar. Yogyakarta. 2007, hlm 17

${ }^{24}$ Mansur, Pendidikan Anak Usia Dini Dalam Islam. Pustaka Belajar. Yogyakarta. 2007, hlm 21

${ }^{25}$ Syamsu Yusuf, Psikologi Perkembangan Anak dan Remaja. PT. Remaja Rosda Karya. Bandung 2004, hlm163
} 
makin sempurna, anak itu lebih dapat menyempurnakan kesanggupannya mengenal. ${ }^{26}$ Perkembangan motorik anak usia dini mencakup motorik kasar (gross motor skills) diperlukan untuk keterampilan menggerakkan dan menyeimbangkan, seperti melompat, meloncat dan berlari dan motorik halus (file motor akills) meliputi perkembangan otot halus dan fungsinya, otot ini berfungsi untuk melakukan gerakan-gerakan yang lebih spesifik; seperti menulis, melipat, merangkai, mengancingkan baju, mengunting dan sebagainya. $^{27}$

b. Perkembangan Kognitif

Perkembangan kognitif bayi pada umumnya sangat berhubungan dengan masa perkembangan motorik bayi, karena modal dasar perkembangan motorik mencerminkan perkembangan kognitif bayi. $^{28}$ Perkembangan kognitif adalah proses dimana individu dapat meningkatkan kemampuan dalam menggunakan pengetahuannya. ${ }^{29}$

Perkembangan kognitif pada usia ini berada pada periode preoperasional yaitu tahapan dimana anak belum mampu menguasai operasi mental secara logis. Yang dimaksud dengan operasi adalah kegiatan-kegiatan yang diselesaikan secara mental bukan fisik. Periode ini ditandai dengan berkembangnya re presentasional atau "symbolic function", yaitu kemampuan menggunakan sesuatu untuk mempresentasikan sesuatu yang lain dengan menggunakan simbol (kata-kata, bahasa gerak, dan benda). ${ }^{30}$ Dalam kehidupan sehari-hari istilah pikiran sering dianggap identik dengan istilah penalaran, kecerdasan, intelegensi. Tetapi bisa diartikan bahwa pikiran adalah hasil kegiatan berfikir, kegiatan berfikir menggunakan sarana atau alat yang disebut akal dan otak. ${ }^{31}$ Perkembangan kognitif menggambarkan bagian

\footnotetext{
${ }^{26}$ Zulkifli, Psikologi Perkembangan. PT. Remaja Rosda Karya. Bandung. 2005, hlm 31

${ }^{27}$ Mansur, Pendidikan Anak Usia Dini Dalam Islam. Pustaka Belajar. Yogyakarta. 2007, hlm 23

${ }^{28}$ Mansur, Pendidikan Anak Usia Dini Dalam Islam. Pustaka Belajar. Yogyakarta. 2007, hlm 29

${ }^{29}$ Mansur, Pendidikan Anak Usia Dini Dalam Islam. Pustaka Belajar. Yogyakarta. 2007, hlm 33-34

${ }^{30}$ Syamsu Yusuf, Psikologi Perkembangan Anak dan Remaja. PT. Remaja Rosda Karya. Bandung 2004, hlm 165

${ }^{31}$ Muhammad Azmi, Pembinaan Akhlak Anak Usia Prasekolah. Belukar. Yogyakarta 2006, hlm 102
} 
pikiran anak berkembang dan berfungsi sehingga dapat berfikir. Semua anak memiliki pola perkembangan kognitif yang sama yaitu:

1) Sensori motorik (0-2 tahun)

2) Preoperasional (2-7 tahun)

3) Konkret operasional (7-11 tahun)

4) Formal operasional (11 tahun keatas)

c. Perkembangan Bahasa

Anak dapat berbicara apabila anak sudah dapat menggunakan bahasa yaitu apabila anak dapat mengeluarkan kata-kata yang berarti untuk dapat berhubungan dengan orang lain. Bayi yang berumur 6 bulan sampai 1 tahun sudah dapat dikatakan dapat berbicara seperti manusia. Pada umur 18 bulan anak sudah dapat mengatakan sesuatu "kata yang berarti" untuk menyatakan suatu kalimat. Pada umur 18 bulan sampai 5 tahun anak berusaha menyatakan sesuatu yang dapat dilihat, didengar dan menambah kata-kata baru. Dan sejak anak berumur 3 tahun anak memperluas perbendaharaan kata-katanya melalui pertanyaan-pertanyaan. ${ }^{32}$

Dalam perkembangan bahasa anak, faktor lingkungan hidup turut mempengaruhinya. Sehingga untuk membantu perkembangan bahasanya maka orang tua, terlebih ibu dan guru taman kanak-kanak harus bisa memfasilitasi dan memberi peluang kepada anak dengan sebaik-baiknya di antaranya melalui tutur kata yang baik dengan anak, mendengarkan pembicaraan anak dan mengajak anak berdialog dalam hal-hal sederhana.

Perkembangan bahasa merupakan salah satu psikis yang harus diperhatikan oleh orang tua sebagai pendidik untuk anak-anaknya. Pada masa ini sebaiknya orang tua membiasakan mengucapkan kata-kata yang baik kepada anaknya, sehingga anak dapat mengucapkannya hingga usia dewasa. ${ }^{33}$

Para ahli berpendapat bahwa secara garis besar ibulah yang membentuk lingkungan berbahasa secara dini. Pada hakikatnya, anak/bayi

${ }^{32}$ Muhammad Azmi, Pembinaan Akhlak Anak Usia Prasekolah. Belukar. Yogyakarta 2006, hlm 105
${ }^{33}$ Muhammad Azmi, Pembinaan Akhlak Anak Usia Prasekolah. Belukar. Yogyakarta 2006, hlm 105 
dan mengeluarkan keinginan atau mengungkapkan sesuatu lahir dari kognitifnya. Perkembangan bahasa merupakan aspek perkembangan kognitif dan karenanya merefleksikan dan bukan mengarahkan kemajuan kognitif. Perkembangan kognitiflah yang menuntun kemahiran berbahasa. Para psikolog perkembangan setuju bahwa kemajuan kognitif merupakan dasar perkembangan bahasa. ${ }^{34}$

d. Perkembangan Moral dan Nilai-nilai Agama

Moral adalah ajaran tentang baik buruk perbuatan dan kelakuan, akhlak dan sebagainya. Moral berkaitan dengan kemampuan untuk membedakan antara perbuatan yang benar dan yang salah, moral merupakan kendali dari tingkah laku. Bagi seorang anak, pengembangan moral akan dikembangkan melalui pemenuhan kebutuhan jasmani, untuk selanjutnya dipolakan melalui pengalaman dalam lingkungan keluarga, sesuai dengan nilai-nilai yang diberlakukannya. ${ }^{35}$ Pada masa ini, anak sudah memiliki dasar tentang sikap moralitas terhadap kelompok sosialnya (orang tua, saudara dan teman sebaya).

Melalui pengalaman berinteraksi dengan orang tua, saudara dan teman sebaya, anak belajar memahami tentang kegiatan atau perilaku mana yang baik, boleh, diterima, disetujui atau buruk, tidak boleh, ditolak, tidak setuju. Maka anak harus dilatih atau dibiasakan mengenal bagaimana dia harus bertingkah laku seperti, mencuci tangan sebelum makan, menggosok gigi sebelum tidur, dan membaca basmalah sebelum makan. ${ }^{36}$

Ada pendapat yang mengatakan bahwa anak sejak lahir telah membawa fitrah keagamaan. Fitrah itu baru berfungsi di kemudian hari melalui proses bimbingan dan latihan setelah berada pada tahap kematangan.

\footnotetext{
${ }^{34}$ Mansur, Pendidikan Anak Usia Dini Dalam Islam. Pustaka Belajar. Yogyakarta. 2007, hlm 42

${ }^{35}$ Muhammad Azmi, Pembinaan Akhlak Anak Usia Prasekolah. Belukar. Yogyakarta 2006, hlm 110

${ }^{36}$ Syamsu Yusuf, Psikologi Perkembangan Anak dan Remaja. PT. Remaja Rosda Karya. Bandung 2004, hlm 175
} 
Perkembanagan pada anak usia dini dengan aspek perkembangan moralitas heteronom. $^{37}$

Perkembangan agama pada anak melalui tiga tingkatan, salah satunya adalah perkembangan agama pada usia 3-6 tahun atau pada masa prasekolah. Pada tingkat ini konsep mengenai Tuhan lebih banyak dipengaruhi oleh fantasi dan emosi, anak menghayati konsep ketuhanan sesuai dengan tingkat perkembangan intelektual. ${ }^{38}$

e. Perkembangan Sosio-Emosional

Perkembangan sosial anak dimulai dari sifat egosentrik, individual, kearah interaktif komunal. Pada mulanya anak bersifat egosentrik, ia tidak mengerti bahwa orang lain bisa berpandangan berbeda dengan dirinya maka usia 2-3 tahun anak masih suka bermain sendiri. Perkembangan sosial meliputi dua aspek penting, yaitu kompetensi sosial dan tanggung jawab sosial. Kompetensi sosial menggambarkan kemampuan anak untuk beradaptasi dengan lingkungan sosialnya secara efektif. Sedangkan tanggung jawab sosial antara lain ditunjukkan oleh komitmen anak terhadap tugastugasnya, menghargai perbedaan, individual, dan memperhatikan lingkungannya. ${ }^{39}$

Pada masa antara 3-5 tahun, sikap sosial yang positif bagi anak akan muncul dan mulai berkembang. Perkembangan sikap sosial didukung oleh perkembangan emosi dan proses berpikir yang semakin meningkat. Hal ini merupakan faktor yang penting bagi anak-anak untuk mencapai sukses dalam melaksanakan tugas perkembangannya. ${ }^{40}$

Emosi merupakan perasaan atau afeksi yang melibatkan perpaduan antara gejolak fisiologis dan perilaku yang terlihat. Pada dua tahun pertama orang tua dalam keluarga mempunyai peranan yang amat penting dan bersifat dominan dalam mengembangkan aspek sosio-emosional anak. Seiring dengan

${ }^{37}$ Mansur, Pendidikan Anak Usia Dini Dalam Islam. Pustaka Belajar. Yogyakarta. 2007, hlm 46

${ }^{38}$ Muhammad Azmi, Pembinaan Akhlak Anak Usia Prasekolah. Belukar. Yogyakarta 2006, hlm 111

${ }^{39}$ Mansur, Pendidikan Anak Usia Dini Dalam Islam. Pustaka Belajar. Yogyakarta. 2007, hlm 56

${ }^{40}$ Muhammad Azmi, Pembinaan Akhlak Anak Usia Prasekolah. Belukar. Yogyakarta 2006, hlm 107 
bertambahnya usia anak, maka perkembangan sosio-emosional dipengaruhi oleh kondisi lingkungan dimana anak melakukan sosialisasi. ${ }^{41}$

Beberapa jenis emosi yang berkembang pada masa anak yaitu takut, cemas, marah, cemburu, kasih sayang, kegembiraan, kesenangan dan kenikmatan serta ingin tahu dan phobi. Phobi yaitu perasaan takut pada objek yang tidak patut ditakuti. ${ }^{42}$

Beberapa aspek perkembangan sosio-emosional yang perlu dikembangkan pada anak usia dini adalah belajar mensosialisasikan diri, belajar berekspresi diri, belajar mandiri dan berdiri sendiri lepas dari pengawasan orang tua atau pengasuh. Belajar bermasyarakat, belajar bagaimana berpartisipasi dalam kelompok, dan belajar mengembangkan daya kepemimpinan. $^{43}$

f. Perkembangan Kreativitas dan Seni

Kreativitas merupakan kemapuan seseorang untuk melahirkan sesuatu yang baru, baik berupa gagasan maupun karya nyata, yang relatif berbeda dengan apa yang telah ada sebelumnya. Secara operasional, kreativitas dapat dirumuskan sebagai kemampuan yang mencerminkan kelancaran, keluwesan (fleksibilitas) dan orisinalitas dalam berpikir serta kemampuan untuk mengelaborasi (mengembangkan, memperkaya memperinci) suatu gagasan. ${ }^{44}$

Pada usia 2 sampai 4 tahun, seorang anak mempunyai kemajuan imajinasi yang besar. Imajinasi ini didasari oleh cara berpikirnya yang masih egosentris. Periode ini merupakan periode yang penting bagi perkembangan kognitif. ${ }^{45}$ Kemampuan pada aspek pengembangan seni dan kreativitas adalah kepekaan terhadap irama, nada, birama, berbagai bunyi, bertepuk tangan serta menghargai karya yang kreatif. Kreativitas lebih banyak ditentukan faktor lingkungan, terutama pola asuh dari orang tuanya. Beberapa pola asuh kreatif

${ }^{41}$ Mansur, Pendidikan Anak Usia Dini Dalam Islam. Pustaka Belajar. Yogyakarta. 2007, hlm 57

${ }^{42}$ Syamsu Yusuf, Psikologi Perkembangan Anak dan Remaja. PT. Remaja Rosda Karya. Bandung 2004, hlm 167

${ }^{43}$ Mansur, Pendidikan Anak Usia Dini Dalam Islam. Pustaka Belajar. Yogyakarta. 2007, hlm 58

${ }^{44}$ Mansur, Pendidikan Anak Usia Dini Dalam Islam. Pustaka Belajar. Yogyakarta. 2007, hlm 59-60

${ }^{45}$ Muhammad Azmi, Pembinaan Akhlak Anak Usia Prasekolah. Belukar. Yogyakarta 2006, hlm 107 
dari orang tua sebenarnya dapat ditumbuhkan dari kehidupan keseharian anak. Fantasi merupakan aktivitas imajinasi untuk membentuk tanggapantanggapan baru dengan pertolongan tanggapan-tanggapan lama yang telah ada dan tanggapan yang baru tidak harus sama atau sesuai dengan bendabenda yang ada. Sifat fantasi anak memiliki tiga ciri yaitu bebas, spontan dan illusionistis. $^{46}$

Seiring dengan fase perkembangan atau aspek-aspek pengembangan anak usia dini, terdapat beberapa karakteristik fase anak kecil (fase anak usia dini) usia sebelum sekolah (3-6 tahun) adalah:

1) Dapat mengontrol tindakannya

2) Selalu ingin bergerak adalah sesuatu yang dialami.

3) Berusaha mengenal lingkungan sekeliling.

4) Perkembangan yang cepat dalam berbicara, oleh karena itu hampir tidak pernah berhenti berbicara dan ini merupakan tabiat yang wajar.

5) Senantiasa ingin memiliki sesuatu dan egois serta mulai pertumbuhannya.

6) Mulai membedakan antara yang benar dan yang salah, yang baik dan yang buruk. Karena itu, sikap memberi kepuasan dan lemah lembut terhadap mereka lebih tepat dari pada memukul dan mengancam.

7) Anak mulai mempelajari dasar-dasar prilaku sosial yang dibutuhkannya saat beradaptasi di sekolah, pada saat mereka masuk kelas 1 .

8) Fase ini merupakan usia eksplorasi. ${ }^{47}$

\section{Pendidikan Anak Usia Dini Dalam Islam}

Pendidikan anak pada dasarnya adalah tanggung jawab orang tua, hanya keterbatasan kemampuan orang tua, maka perlu adanya bantuan dari orang lain yang mampu dan mau membantu orang tua dalam pendidikan anak-anaknya terutama dalam mengajar berbagai ilmu dan keterampilan yang selalu berkembang dan dituntut pengembangannya bagi kepentingan manusia. Secara

${ }^{46}$ Muhammad Azmi, Pembinaan Akhlak Anak Usia Prasekolah. Belukar. Yogyakarta 2006, hlm 106

${ }^{47}$ Abu Amir Ahmad Sulaiman, Metode Pendidikan Anak Muslim Usia Prasekolah. Yayasan Al-Qur'an-

Sofwa. Jakarta, 2000, hlm 10 
ideal, pendidikan tidak harus dilaksanakan ketika anak telah lahir tapi pada saat pre-natal anak juga harus mendapatkannya. Dan sesungguhnya pendidikan prenatal tidak saja dimulai ketika anak berada dalam kandungan, tetapi sejak konsepsi. Bahkan ada beberapa pendapat yang mengatakan bahwa pendidikan anak sebenarnya dimulai sejak masa prakonsepsi yakni sebelum seorang memiliki seorang perempuan untuk dijadikan istrinya. ${ }^{48}$

Dalam Islam, kita menemukan dua konsep ajaran Rasulullah SAW yang maknanya sangat padat dan memiliki kaitan erat dengan tujuan pendidikan yaitu iman dan taqwa.

Pendidikan memiliki peranan sentral untuk memelihara sopan santun dan adab. Sehingga, pendidikan hendaknya diarahkan untuk menata hidup manusia agar selalu berakhlakul karimah, sebagai pribadi, anggota masyarakat dan selaku hamba Allah SWT agar hidup maslahat di dunia dan di akhirat. Ini berarti pada dasarnya pendidikan anak merupakan upaya menyiapkan manusia agar tetap mampu memelihara keyakinan, ikhlas, menunaikan fardhu, menunaikan amal sunah, serta berbuat sopan santun dan adab. ${ }^{49}$

Aspek penting dalam mendidik, yang harus ditanamkan kepada anak adalah aspek iman dan akhlak. Oleh karena itu, beberapa isyarat atau petunjuk tentang pendidikan anak sebagaimana dikisahkan di dalam Al-Qur'an surat Luqman bahwa yang pertama kali diajarkan adalah tauhid kemudian dengan pendidikan akhlak. ${ }^{50}$

\section{a. Materi Pendidikan Anak Usia Dini}

Dalam Islam, pendidikan bagi anak usia dini (prasekolah) setidaknya memuat materi tentang iman dan akhlak. Hal ini berpangkal dari ayat-ayat yang terdapat di dalam surat Luqman ayat 12-19. Materi pendidikan keimanan tidak dipisahkan dari kehidupan dan perilaku sehari-hari. Wujud

\footnotetext{
${ }^{48}$ Agus Purnomo. Egalita, Jurnal Kesetaraan \&Keadilan Gender. No 2. PSG UIN Malang. Malang. 2007. Hlm 261

${ }^{49}$ Ahmad Tafsir, Pendidikan Agama Dalam Keluarga. PT. Remaja Rosdakarya. Bandung. 2002. Hlm 69

${ }^{50}$ Agus Purnomo. Egalita, Jurnal Kesetaraan \&Keadilan Gender. No 2. PSG UIN Malang. Malang. 2007. HIm 221
} 
dari iman itu harus nampak pada berbagai kecakapan seperti, menghafal berbagai do'a, ayat Al-Qur'an hafal bacaan sholat, serta sopan santun kepada orang tua dan anggota keluarga lainnya. ${ }^{51}$ Adapun beberapa materi pendidikan Islam yang perlu diberikan kepada anak didik, agar tujuan pendidikan dapat tercapai adalah materi pendidikan Aqidah, Ibadah, Akhlak, Jasmani, Rohani, Intelektual dan Sosial. ${ }^{52}$

b. Metode Pendidikan Anak Usia Dini

Metode pembelajaran atau pendidikan untuk anak usia dini hendaknya menantang dan menyenangkan, melibatkan unsur bermain, bergerak, bernyanyi dan belajar. ${ }^{53}$ Beberapa pakar pendidikan mengemukakan beberapa metode pendidikan Islam, diantaranya adalah metode hiwar (dialog), metode kisah (cerita), metode amsal (perumpamaan), metode keteladanan dan metode pembiasaan. $^{54}$

\section{Peran Ibu Dalam Pendidikan Anak Usia Dini}

Kaum ibu memiliki peran yang multidimensional, di satu sisi kaum ibu tidak dapat dielakkan peranannya di sektor publik bersama kaum pria dalam mencurahkan perhatiannya dalam pembangunan keluarga, masyarakat, bangsa dan bumi pertiwi. Sedangkan di sisi lain yaitu pada sektor domestik, mereka adalah penyalur dan pembina kehidupan yang keberadaannya berpengaruh besar sebagai modal dasar dari segala bentuk hubungan manusiawi, dalam hal melahirkan dan membentuk generasi baru yang lebih berkualitas.

Peran wanita muslimah dalam pergerakan Islam dimulai sejak ia menyiapkan iklim yang kondusif bagi suaminya dan membantunya untuk melaksanakan risalahnya terhadap agama dan dakwahnya. Membantu suami dengan baik, merawatnya dan mendidik anak-anak menurut prinsip Islam

\footnotetext{
${ }^{51}$ Ahmad Tafsir, Pendidikan Agama Dalam Keluarga. PT. Remaja Rosdakarya. Bandung. 2002. Hlm 87

${ }^{52}$ Muhammad Azmi, Pembinaan Akhlak Anak Usia Prasekolah. Belukar. Yogyakarta 2006, hlm 37

${ }^{53}$ Slamet Suyanto._Dasar-dasar Pendidikan Anak Usia Dini. Hikayat Publishing. Yogyakarta. 2005, hlm 144

${ }^{54}$ Muhammad Azmi, Pembinaan Akhlak Anak Usia Prasekolah. Belukar. Yogyakarta 2006, hlm 31
} 
termasuk inti amal bakti istri, sebab peran penting yang bisa dipersembahkan wanita pada gerakan Islam adalah rumah Muslim teladan. ${ }^{55}$

Wanita yang berperan sebagai ibu bagi anak-anaknya, memiliki potensi besar yang lebih mandiri. Peran sentralnya sebagai salah satu tokoh kunci dalam proses pendidikan yang pertama dan utama bagi anak-anaknya, telah membangun jiwa perempuan sebagai pribadi yang tangguh. Peran perempuan (wanita) sebagai ibu bukannlah peran tunggal, namun peran berganda bahkan berlapis-lapis. ${ }^{56}$

Pada lazimnya sebuah keluarga beranggotakan ayah, ibu dan anak-anak. Seorang ayah adalah inspirator keluarga yang memberikan ilham keteladanan, sedangkan dalam pengembangan potensi keluarga adalah peran dan fungsi seorang ibu. Fungsi seorang ibu adalah pengemban amanah, terutama dalam hal dukungan moral atau spiritual. Bakat kelembutan, ketelatenan dan kasih sayang yang terpancar dari pribadi seorang ibu berfungsi sebagai perekat hubungan antara sesama anggota keluarga. ${ }^{57}$

Ibu adalah madrasah pertama untuk anak-anaknya, tempat dimana anak mendapatkan asuhan dan diberi pendidikan pertama sejak dalam kandungan. Sehingga ikatan emosional seorang ibu dan anak tampak lebih dibandingkan seorang ayah. Di satu sisi, selain wanita (ibu) berperan sebagai pendidik dan pembimbing anak-anak, yang merupakan sekolah pertama baginya, ibu juga berperan sebagai istri yang mempunyai tugas-tugas utama dalam mengabdi pada keluarganya.

Tugas pokok seorang istri secara umum sebagai ibu, yang berkaitan langsung dengan memenuhi fungsi reproduksi serta fungsi edukasi, dan sebagai pengatur (manager) rumah tangga, yang berkaitan dengan pemenuhan fungsifungsi keluarga yang lainnya.

\footnotetext{
${ }^{55}$ Mahmud Muhammad Al-jauhari, Membangun Keluarga Qur'ani: Panduan Untuk Wanita Muslimah. Amzah. Jakarta. 2005, hlm 276-277

${ }^{56}$ Agus Purnomo. Egalita, Jurnal Kesetaraan \&Keadilan Gender. No 2. PSG UIN Malang. Malang. 2007. Hlm 227

${ }^{57}$ Abang Eddy, Adriansyah, Jendela Keluarga. MQ Publishing. Bandung. 2004, hlm 138
} 
Gambaran seorang ibu sesuai dengan fungsi dan tanggung jawabnya dalam pendidikan anak-anaknya dapat disimpulkan sebagai berikut:

a. Sumber dan pemberi rasa kasih sayang.

b. Pengasuh dan pemelihara.

c. Tempat mencurahkan isi hati.

d. Pengatur kehidupan dalam rumah tangga.

e. Pembimbing hubungan pribadi.

f. Pendidik dalam segi-segi emosional.

Walaupun fungsi dan tanggung jawab tersebut masih berlaku umum, namun hal itu menjadi fungsi dan tanggung jawab pokok dalam ajaran Islam yang bersumber dari ayat-ayat Al-Qur'an dan Al-Sunah yang seharusnya dilakukan oleh kaum ibu terhadap pendidikan anak-anak mereka. ${ }^{58}$

Jadi, wanita memiliki peran cukup besar dan menciptakan sebuah kehidupan yang penuh arti. Dalam kehidupan ini terdapat sederetan aktifitas dan kegiatan yang tidak dapat dijalankan laki-laki. Di antaranya, mengasuh dan mengajar anak-anak, merawat orang sakit dan sebagainya. ${ }^{59}$ Dan agar tidak terjadi ketimpangan peran, ada beberapa hal yang seharusnya diperhatikan wanita muslimah, yaitu sebagai berikut :

a. Berburu pengalaman pada wanita muslimah lain dalam hal mengatur manajemen rumah tangga, urusan masak-memasak, dan kecepatan bertindak.

b. Berusaha semaksimal mungkin untuk melaksanakan kewajiban dan keinginan suami.

c. Memfokuskan perhatian pada pendidikan anak, khususnya pada fase pertama usia mereka dan biasakan mereka untuk mandiri mengerjakan hal yang sederhana. $^{60}$

\section{Kedudukan Ibu Dalam Keluarga}

${ }^{58}$ Djumransyah, Pendidikan Islam Menggali "Tradisi", Meneguhkan Eksistensi. UIN-Malang Press. Malang. 2007, hlm 85-86

${ }^{59}$ Mansur, Pendidikan Anak Usia Dini Dalam Islam. Pustaka Belajar. Yogyakarta. 2007, hlm 190

${ }^{60}$ Mahmud Muhammad Al-jauhari, Membangun Keluarga Qur'ani: Panduan Untuk Wanita Muslimah.

Amzah. Jakarta. 2005, hlm 278 
Setelah Islam datang, mulai ada perubahan dimana kedudukan wanita diangkat oleh Islam. Islam mengangkat derajat wanita dan memberikan kepadanya hak sebagai manusia yang sebelumnya tidak pernah diberikan kepada wanita. ${ }^{61}$ Islam telah memposisikan ibu di tempat yang terhormat. Di lingkungan keluarga, ibu sebagai seorang ibu, istri sekaligus pengurus rumah tangga. Di lingkungan masyarakat, ibu merupakan anggota yang tidak dapat dikesampingkan karena dia merupakan pencetak dan pembentuk generasi. Sedangkan di lingkup Negara, ibu merupakan tiang Negara, yang apabila rapuh maka negara tidak akan dapat berdiri tegak, Oleh karena itu, ibu sebagai pendamping suami, pendidik anak dan pengurus rumah tangga berperan penting dalam berbagai upaya mewujudkan manusia-manusia yang berbudi luhur, berakhlak mulia, berperikemanusiaan, berkepribadian teguh. ${ }^{62}$

Wanita dalam Islam merupakan cermin keberadaan Islam. Bilamana masyarakat Islam berjaya maka kedudukan kaum wanitanya pun akan demikian. Sebaliknya jika keberadaan Islam dalam masyarakat itu terancam dan dibawah tekanan, maka kondisi kaum wanitanya juga demiian. ${ }^{63}$ Islam telah menyamakan antara laki-laki dan ibu dalam memperoleh hak-hak kemanusiaan, juga menyamakan antara keduanya dalam melakukan kewajiban kemanusiaan, karena keduanya telah diikat sebagai khalifah di muka bumi yang selalu melakukan perbaikan dan pembangunan didalamnya serta aktif beribadah. Islam telah memberikan tugas pada keduanya untuk mendirikan masyarakat atau manusia yang beradab serta saling melengkapi dan bukan saling bertentangan. ${ }^{64}$

Ibu tidak hanya berada pada wilayah domestik, tapi juga publik dan politik. Dengan kata lain perempuan mulai diberi hak yang setara dengan lakilaki, yang sebelumnya tidak ia dapatkan seperti hak berkiprah di luar rumah, hak untuk mendapatkan pengajaran dan lain-lain. Posisi atau kedudukan ini semakin meningkat kualitasnya ketika perempuan tersebut menjadi ibu. Ia dihargai tiga

\footnotetext{
${ }^{61}$ Mansur, Pendidikan Anak Usia Dini Dalam Islam. Pustaka Belajar. Yogyakarta. 2007, hlm 196

${ }^{62}$ Muhammad Ali Al-Hasyimi, Jati Diri Wanita Muslimah. Pustaka Al-Kausar. Jakarta. 2008, hlm 8

${ }^{63}$ Mansur, Pendidikan Anak Usia Dini Dalam Islam. Pustaka Belajar. Yogyakarta. 2007, hlm 193

${ }^{64}$ Muhammad Ali Al-Hasyimi, Jati Diri Wanita Muslimah. Pustaka Al-Kausar. Jakarta. 2008, hlm 89
} 
kali lipat dari harga laki-laki. Akan tetapi laki-laki dan perempuan dalam AlQur'an sama-sama menerima perjanjian primordial dan memiliki peluang yang sama untuk berprestasi. ${ }^{65}$

Al-Qur'an dengan jelas menekankan bahwa pernikahan dalam Islam adalah kasih dan sayang antara dua insan yang berbeda jenis dan masyarakat dengan tujuan mempertahankan keturunan dan menciptakan ketentraman dan keharmonisan. Sebagai mana dalam Al-Quran Surat Ar-Rum ayat 21:

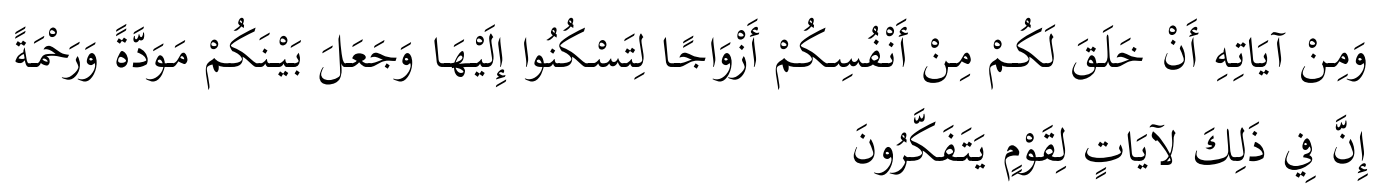

"Dan diantara tanda-tanda kekuasan-Nya ialah Dia menciptakan untukmu istriistri dari jenismu sendiri supaya kamu cenderung dan merasa tentram kepadanya, dan dijadikan-Nya diantara kamu rasa kasih dan sayang. Sesungguhnya pada yang demikian itu benar-benar terdapat tanda-tanda bagi kaum yang berfikir. ${ }^{66}$

Di dalam kedudukannya wanita yang menjadi ibu rumah tangga, Islam berwasiat untuk menghormati dan memuliakan ibu, seperti juga telah berwasiat untuk menghargai dan menjunjung tinggi ayah. ${ }^{67}$ Hal ini sesuai dengan firman Allah SWT dalam surat An-nisa' ayat 36:

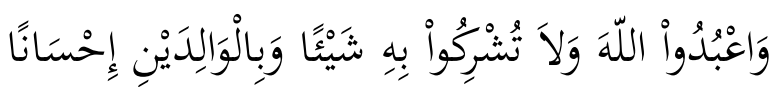

"Sembahlah Allah dan janganlah kamu mempersekutukan-Nya dengan sesuatupun. Dan berbuatlah baik kepada dua orang ibu-bapak....... 68

Di antara yang memenuhi jiwa wanita muslimah baik itu berupa kebahagiaan, kerelaan, ketenangan dan kebanggaan serta bertambahnya tinggi kedudukannya adalah ditempatkannya posisi ibu di atas posisi bapak. ${ }^{69}$ Dalam

\footnotetext{
${ }^{65}$ Waryono Abdul Ghafur. Strategi Qur'ani: Mengenali Diri Sendiri dan Meraih Kebahagiaan Hidup. Belukar Budaya. Yogyakarta. 2004, hlm 181

${ }^{66}$ Departemen Agama RI, Al-Qur'an dan Terjemahnya. CV. Penerbit J-ART. Bandung. 2005. Hlm 407

67 Ibrahim Muhammad Al-Jamal, Tantangan Wanita Muslimah. Pustaka Azzam. Jakarta. 2000, hlm 29

${ }^{68}$ Departemen Agama RI, Al-Qur'an dan Terjemahnya. CV. Penerbit J-ART. Bandung. 2005. Hlm 85

${ }^{69}$ Muhammad Ali Al-Hasyimi, Jati Diri Wanita Muslimah. Pustaka Al-Kausar. Jakarta. 2008, hlm 92
} 
sabda Nabi Muhammad SAW ketika itu ada seorang laki-laki yang datang kepada Nabi, seraya bertanya kepadanya:

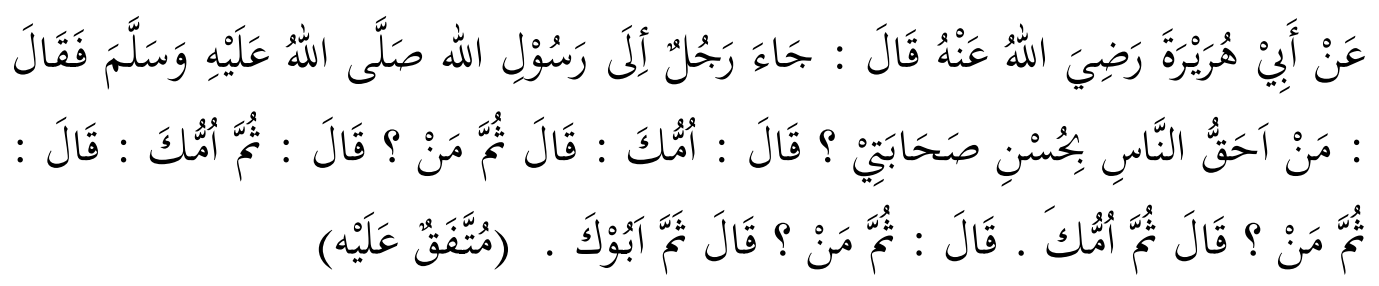

"Abu Hurairah mengatakan bahwa seorang laki-laki datang kepada Rasulullah SAW lalu dia bertanya: siapakah orang yang lebih berhak mendapatkan kebaktian? Rasulullah menjawab; "ibumu". orang itu bertanya lagi, lalu siapa? Rasulullah menjawab; "ibumu". Orang itu bertanya lagi, setelah itu siapa? Rasulullah menjawab; "ibumu”. Orang itu bertanya lagi, kemudian siapa? Rasulullah menjawab; kemudian ayahmu “. 70

Dalam hadist tersebut menunjukkan bahwa kedudukan ibu sangatlah tinggi. Demikian pula, ibu diistimewakan penciptaan dan bentuknya serta tugasnya, mengandung, menyusui, dan mengasuh anak. Sesungguhnya semua itu merupakan tugas yang sangat berat dan pekerjaan yang tidak ringan. ${ }^{71}$

Dalam firman Allah, surat Lukman ayat 14, dijelaskan :

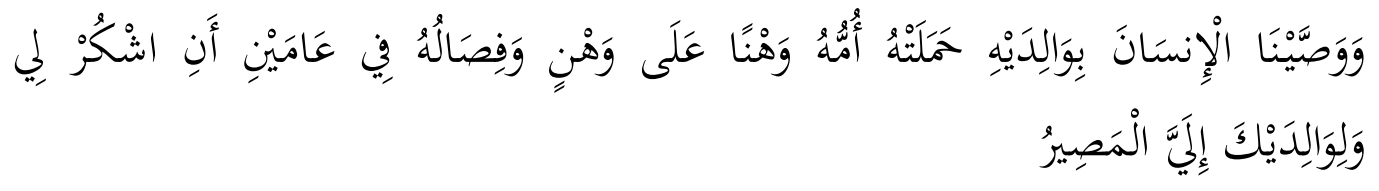

"Dan Kami perintahkan kepada manusia (berbuat baik) kepada kedua orang tua ibu bapaknya, ibunya telah mengandungnya dalam keadaan lemah yang bertambah-tambah dan menyapihnya dalam dua tahun. Bersyukurlah kepadaKu dan kepada dua orang ibu bapakmu, hanya kepada-Kulah kembalimu,"72.

\section{Peran Ibu Dalam Proses Pendidikan Anak Usia Dini Menurut Al-Qur'an}

Peran ibu adalah subjek utama dalam pengasuhan anak, mereka adalah para pencetak generasi bangsa. Bahkan terdapat suatu ungkapan yang menyatakan bahwa ibu adalah tiang Negara. Hal ini dimaksudkan karena melalui seorang ibulah generasi bangsa/anak-anak mendapatkan pendidikan untuk pertama kalinya. Apabila pendidikan yang diperoleh anak-anak itu baik, maka

\footnotetext{
${ }^{70}$ Abu Zakaria Al-Ansori, Riyadussolihin, Muttafaqun 'Alaih

${ }^{71}$ Muhammad Ali Al-Hasyimi, Jati Diri Wanita Muslimah. Pustaka Al-Kausar. Jakarta. 2008, hlm 92

${ }^{72}$ Departemen Agama RI, Al-Qur'an dan Terjemahnya. CV. Penerbit J-ART. Bandung. 2005. Hlm 413
} 
baik pula masa depan bangsa, begitu juga sebaliknya. Dalam pendidikan Islam, anak dilahirkan ke dunia dalam keadaan yang jauh dari sempurna dan anak berada dalam ketidak berdayaan. Maka orang tua (ibu dan bapak) yang harus mengembangkan anak yang lahir di dalamnya. Proses pengembangan anak dimaksud adalah pembentukan anak baik secara fisik maupun psikis, watak maupun kepribadiannya. ${ }^{73}$

Anak usia dini merupakan kelompok anak yang berada dalam proses pertumbuhan dan perkembangan yang bersifat unik, dalam arti memiliki pola pertumbuhan dan perkembangan yang khusus sesuai dengan tingkat pertumbuhan dan perkembangan anak. ${ }^{74}$

Sehubungan dangan pendidikan anak juga telah dijelaskan dalam pasal 1 butir 14 UU No. 20 tahun 2003 SISDIKNAS tentang pendidikan anak usia dini, bahwa pendidikan anak usia dini (PAUD) merupakan suatu upaya pembinaan yang ditujukan kepada anak sejak lahir sampai dengan usia enam tahun yang dilakukan melalui pemberian rangsangan pendidikan untuk membantu pertumbuhan dan perkembangan jasmani dan rohani agar anak memiliki kesiapan dalam memasuki pendidikan lebih lanjut.

Pentingnya terselenggaranya pendidikan anak usia dini lebih khusus dijelaskan dalam pasal 28 UU No. 20 tahun 2003, SISDIKNAS. Yang mana pada butir kelima dikemukakan bahwa pendidikan anak usia dini pada jalur pendidikan informal berbentuk pendidikan keluarga atau pendidikan yang diselenggarakan oleh lingkungan.

Dengan mengingat pentingnya pendidikan anak usia dini, maka seyogyanya seorang ibu harus menyediakan waktu, perhatian, dan asuhan kepada anak karena pada masa tersebut adalah masa kritis. Seorang ibu harus mampu mendidik anak-anaknya dengan rasa cinta dan kasih sayang yang benar, sehingga anak-anaknya pun akan mempunyai rasa cinta dan kasih sayang yang benar pula terhadap orang tua dan keluarganya. Rasa cinta dan kasih sayang

${ }^{73}$ Sama'un Bakry, Menggagas Ilmu Pendidikan Islam. Pustaka Bani Quraisy. Bandung. 2005,hlm 104

${ }^{74}$ Mansur, Pendidikan Anak Usia Dini Dalam Islam. Pustaka Belajar. Yogyakarta. 2007, hlm 88 
yang benar adalah yang mendahulukan rasa cinta kepada Allah dan Rasul-Nya diatas segalanya.

Pendidikan yang diberikan oleh seorang ibu lebih bersifat pada pemberian kasih sayang, bukan mendidik dengan keras, karena akan membentuk anak berjiwa keras dan kepribadian anak cenderung dengan kekerasan hati, pikiran, gerak dan perkataannya jauh dari kebenaran. Kelembutan, kemesraan dalam mendidik anak merupakan konsep Al-Qur'an. Dalam prioritas mendidik anak diutamakan mendidik aqidahnya terlebih dahulu, dengan menyampaikan yang lembut dan kasih sayang, karena aqidah merupakan pondasi dasar bagi manusia untuk mengarungi kehidupan dan aqidah adalah asas untuk membangun Islam. Apabila asasnya sudah bagus maka Islam akan tegak dalam diri anak. Setelah itu anak dididik pada aspek ibadah.

Pendidikan pertama yang harus diberikan pada anak adalah penanaman aqidah yang benar, selanjutnya adalah mendidik anak agar mencintai dan mendirikan sholat 5 waktu dengan sadar tanpa ada paksaan. Dan ketiga adalah mendidik anak untuk berjiwa pendakwah yaitu suka memberi contoh dalam berbuat baik dan meninggalkan kemungkaran. Kemudian yang keempat adalah menekankan pendidikan pada aspek akhlak yang mulia.

Dalam surat Lukman juga dijelaskan bahwa dalam mendidik terdapat dua aspek penting yang harus diberikan pada anak usia dini baik untuk anak laki-laki maupun perempuan yakni aspek iman dan akhlaq. Dimana aspek iman adalah dengan mengenal Tuhan (tauhid) dan menanamkan aqidah (kepercayaan) sedangkan aspek akhlaq adalah dengan ibadah dan keteladanan sehingga dalam memberikan pendidikan anak dapat dilakukan dengan metode keteladanan dan pembiasaan dari orang tua, khususnya seorang ibu yang selalu mendampingi dan selalu berinteraksi setiap saat dengan anak.

\section{Kesimpulan}

Berdasarkan uraian pada bab-bab di atas, maka dalam bab ini penulis mengambil kesimpulan bahwa: 
1. Anak-anak pada masa usia dini sangatlah memerlukan peran seorang ibu, hal tersebut untuk mendapatkan curahan kasih sayang dan kelembutan. Bahkan sejak dalam kandungan sampai ia lahir dan tumbuh menjadi dewasa. Akan tetapi, pada masa usia dini inilah peran ibu sangat pokok dan utama diperlukan bagi kelanjutan pertumbuhan dan perkembangan anaknya. Sebab, peran ibu pada masa tersebut merupakan fundamen awal bagi anak untuk mengenal dunia sekitarnya.

2. Peran ibu adalah sebagai pendidik dan pembimbing anak-anak yang merupakan sekolah pertama baginya. Hal ini merupakan peran sentralnya sebagai salah satu tokoh kunci dalam proses pendidikan yang pertama dan utama bagi anakanaknya. Seorang ibu yang mempunyai peran penting tersebut seharusnya mempunyai kemampuan intelek atau kecerdasan yang mumpuni dan bijaksana serta mempunyai keikhlasan dan rasa kasih sayang dalam mendidik anakanaknya, terutama pada masa-masa usia dini baik dalam hal pendidikan maupun yang lainnya. Sehingga seorang anak diharapkan dapat mencapai tingkat kecerdasan yang tinggi pula untuk kesuksesan masa depannya.

Seorang ibu memegang peran yang penting dalam keluarga, terutama terhadap pendidikan anak-anaknya. Sehingga pendidikan yang diberikan seorang ibu merupakan pendidikan dasar yang tidak bisa dianggap ringan. Pendidikan yang diberikan oleh ibu dimulai sejak usia dini, bahkan sebelum anak dilahirkan. Dan di dalam Islam disinggung pada surat Luqman ayat 12-19 yang menjelaskan bahwa di dalam mendidik, yang harus diberikan pada anak di usia dini adalah aspek iman dan akhlaq yang diaplikasikan melalui keteladanan dan pembiasaan serta kasih sayang yang dimiliki oleh seorang ibu dengan kelembutan, kemesraan, kasih sayang serta perhatian dan dorongan seorang ibu maka akan dapat membentuk sifat dan karakter anak dengan baik secara maksimal tentunya sesuai dengan proses pertumbuhan dan perkembangan anak.

Sebagaimana kesimpulan yang tersebut diatas, maka penulis mengemukakan beberapa saran. Adapun saran-saran yang hendak disampaikan adalah sebagai berikut: 
1. Pentingnya peran ibu dalam proses pendidikan anak, sehingga diharapkan pemerintah dan khususnya para ibu untuk mendukung dan mengembangkan ketrampilan serta pengetahuan tantang pendidikan anak sejak dini.

2. Tingkat pemahaman dan pengetahuan yang dimiliki para ibu dalam memahami pertumbuhan dan perkembangan anak perlu mendapatkan penyuluhan atau pembelajaran-pembelajaran khusus, karena hal tersebut sangat membantu proses pendidikan anak sejak dini terutama dalam hal moral, agama serta tingkat kecerdasan yang dimiliki anak.

3. Pendidikan anak usia dini hendaknya diberikan sedini mungkin bahkan sebelum anak dilahirkan, baik oleh keluarga, maupun masyarakat. Hal tersebut dikarenakan pendidikan yang diberikan oleh keluarga, kuhususnya ibu merupakan pendidikan yang fundamental dan karena tingkat kecerdasan anak mulai dibentuk pada rentang anak usia dini.

\section{DAFTAR PUSTAKA}

Abu Amr Ahmad Sulaiman, 2000, Metode Pendidikan Anak Muslim Usia Prasekolah. Jakarta: Yayasan Al-Qur'an-Sofwa

Abu Zakaria Al-Ansori, Riyadussolihin, Muttafaqun 'Alaih

Adriansyah, Abang Eddy, 2004, Jendela Keluarga. Bandung: MQ Publishing

Ahmad Munir, 2008, Tafsir Tarbawi: Mengungkap Peran Al-Qur'an Tentang Pendidikan. Yogyakarta: Teras

Ahmad Tafsir, 2002, Pendidikan Agama Dalam Keluarga. Bandung: PT. Remaja Rosdakarya.

Arikunto, Suharsimi, 2006, Prosedur Penelitian Suatu Penelitian Praktik. Jakarta: PT. Asdi Mahasatya.

Cendikia, Jurnal kependidikan dan kemasyarakatan. No. 1 Tahun 2005. Ponorogo: STAIN Ponorogo

Daradjat, Zakiyah, 1994, Pendidikan Islam Dalam Sekolah dan Keluarga. Jakarta: PT. Ruhama 
Djumransyah, 2007, Pendidikan Islam Menggali "Tradisi", Meneguhkan Eksistensi. Malang: UIN-Malang Press

Departemen Agama RI, 2005. Al-Qur'an dan Terjemahnya. Bandung : CV. Penerbit JART

Egalita, Jurnal Kesetaraan \&Keadilan Gender. No 2 Tahun 2007. Malang: PSG UIN Malang.

Ghafur, Waryono Abdul, 2004, Strategi Qur'ani: Mengenali Diri Sendiri dan Meraih Kebahagiaan Hidup. Yogyakarta: Belukar Budaya.

Ibrahim Muhammad Al-Jamal, 2000, Tantangan Wanita Muslimah. Jakarta: Pustaka Azzam.

M. Arifin. 1996. Ilmu Pendidikan Islam. Jakarta: Bumi Aksara.

Mahmud Muhammad Al-jauhari, 2005, Membangun Keluarga Qur'ani: Panduan Untuk Wanita Muslimah. Jakarta: Amzah.

Mansur, 2007, Pendidikan Anak Usia Dini Dalam Islam. Yogyakarta: Pustaka Belajar

Margono, S, 2003, Metodologi Penelitian Pendidikan. Jakarta: PT. Rieneka Cipta.

Muhammad Ali Al-Hasyimi, 2008, Jati Diri Wanita Muslimah. Jakarta: Pustaka AlKausar.

Muhammad Azmi, 2006, Pembinaan Akhlak Anak Usia Prasekolah. Yogyakarta: Belukar

Patalima, Hamid, 2005, Metode Penelitian Kualitatif. Bandung: Alfabeta.

Purwanto, Ngalim, 2007, Ilmu Pendiidkan Teoritis dan Praktis. Bandung: Rosdakarya.

Sayid Muhammad Husain Fadhullah, 2002, Dunia Wanita Dalam Islam. Jakarta: Lentera Baristama.

Sama'un Bakry, 2005, Menggagas Ilmu Pendidikan Islam. Bandung: Pustaka Bani Quraisy

Shihab, M. Quraish, 2007. Membumikan Al-Qur'an. Bandung: Mizan

Soejanto, Agoes, 2005. Psikologi Perkembangan. Jakarta: PT. Rieneka Cipta. 
Sugiyono, 2008, Metode Penelitian Pendidikan. Bandung: Alfabeta.

Suyanto, Slamet, 2005, Dasar-dasar Pendidikan Anak Usia Dini. Yogyakarta: Hikayat Publishing.

Syaiful Bahri Djamarah, 2008, Psikologi Belajar. Jakarta: PT. Rieneka Cipta

Syamsu Yusuf, 2004, Psikologi Perkembangan Anak dan Remaja. Bandung: PT. Remaja Rosda Karya.

Terjemah Tafsir Al-Qur'an-Maraghi, Jilid 30

Zulkifli, 2005, Psikologi Perkembangan. Bandung: Bandung: PT. Remaja Rosda Karya. 